\title{
The comparative economic analysis of Hungarian and German apple production of good standard
}

\author{
Apáti, F. \\ University of Debrecen Centre for Agricultural Sciences and Engineering \\ H-4032 Debrecen Böszörményi St. 138
}

\begin{abstract}
Summary: The profitability of the Hungarian apple production considering firms producing on high standard is not lagged behind significantly from that of German firms, moreover in certain cases it reflects a more positive situation. It is unfavourable, however, that this statement is true only for 8 to $10 \%$ of our whole apple plantation surface. The results of the investigations highlighted the fact that in comparison with Germany our farm business advantages manifest in three factors: in 70 to $80 \%$ lower wages, in 15 to $30 \%$ higher investment and subsidy intensity and in the fact that at present we cannot neglect the ice safety system which is rather expensive. By the increasing wages, the narrowing subsidy opportunities and incidentally the appearing harmful weather phenomenon, these advantages may be continuously ceased. Our definite disadvantage appears in the level of marketing price, considering the fact that producers in Hungary realize 30 to $35 \%$ lower marketing price, which is in connection with the probably much lower level of organization among farmers, in the market and in the logistical background.
\end{abstract}

Key words: apple production, economic efficiency, competitiveness

\section{Introduction}

Changes of the economic and market environments, setting the fields and tendencies of the sector development, as well as the present situation of our apple enterprise all equally justify and make investigating the comparativeness, profitability and efficiency of the Hungarian apple production important in a highlighted way.

Because of the extremely heterogeneous feature of the participants in the Hungarian apple enterprise, especially in case of size, state of productive stock, technical knowledge and capital strength, it is not practical to focus on enterprise averages within the farm business analysis forming the object of the research. In this way in my thesis I concentrate only on a narrower producer segment (on a more homogenous sample), on firms producing on good standard, which may form the significance of the Hungarian apple production in the future, that is they are capable of operating in an efficient, economic and competitive way by all odds. As these concepts are extremely relative, their precise determination is possible only by comparing them to something. When choosing the comparing basis it is practical to compare ourselves to a Western-European country having a developed horticulture. My choice was Germany for several reasons, which is the fourth biggest apple producing member state of the European Union.
Regarding the above mentioned, I set the general objectives of my research as follows:

1. Evaluating the efficiency as well as the short and long run economy as the basically factors determining competitiveness of the Hungarian apple production in an absolute way.

2. Evaluating the efficiency and economy of the Hungarian apple production in a relative way by the complex comparative economic analysis of the Hungarian and German apple production of good standard, determining our advantages and disadvantages with respect to these factors.

I set two basic research hypotheses in harmony with the general objectives, which are the followings:

1. The production in Hungarian apple producing firms of good standard may be carried out in an appropriate efficient and economic way.

2. Firms producing of good standard in Germany are able to reach more favourable efficiency and better economic parameters than in Hungary.

I endeavor to fulfill the following specific objectives in connection with the general objectives by analyzing both countries one by one then comparing them:

1. What characterizes the natural inputs, costs and as well as their structure? 
2. What output levels and parameters (yield, quality, marketing price, production value) characterize the production?

3. What are the tendencies of the efficiency and economies of production from short-term and longterm aspects?

4. What characterizes the profitability if the different states of external environment, such as investment subsidies, yields, quality and marketing price are changing?

5. How is the profitability of the Hungarian apple production in harmony with that of German apple production, in which factors do our advantages and disadvantages appear?

In order to realize the specific objectives, and answer $\mathrm{F}$ questions, I find completing the following tasks necessary:

1. Analyzing the standard and structure of the natural inputs and production costs for the two periods of the plantation lifetime, that is setting apart to the periods of investment and productive age.

2. Evaluating the output conditions (yield, quality, marketing price, production value) being typical to the productive period.

3. Making a detailed analysis of the results of the farming and the efficiency of production in the productive period (short-term view), as well as carrying out an investment appraisal for the whole lifecycle of the plantation (long-term view).

4. Making a sensitivity analysis for the profitability of the production to simulate the effects of the different states of the economic and natural environment.

5. Determining our farm business advantages and disadvantages based on the results of the examination above mentioned.

\section{Materials and methods}

\section{The object of the research, the investigated ventures}

According to the objectives, the research focuses on just the ventures producing on good standard. This is basically the segment which is expected to most probably operate in an effective and competitive way, thus my results and conclusions refer to these ventures and plantations with respect to both countries.

The good production standard may be hardly defined, and is an extremely relative concept. The production standard is determined by several factors but first of all by the factors of output, such as yields and product quality. Thus during my work, I selected the firms being classified into this group according to professional and experimental way on one hand, and on the basis of the following rule on the other hand: a firm or a plantation is considered to produce on a good standard considering the present expectations if it is able to realize an average yield of 30 tons per hectare for a long run, from which at least $80 \%$ is of food quality.

It is also important to fix the fact that the plantation surface characterized by this concept in Hungary makes up 3000 to 4000 hectares of the present total 40000 hectares according to the plantations on one hand, and to my estimation on the consumer side on the other hand, thus the results of my investigation focus only on this segment constituting approximately $10 \%$.

\section{Parameters of the examined plantations}

Taking the European and domestic tendencies into consideration, it is probable that the majority of the productive area, just like in Germany nowadays, will be standing on weak growing rootstock (typically M9 rootstock), will be of thick spatial position (line width of 3,0 to 4,0 meters and stock width of 0,7 to 1,5 meters), having great number of stocks per hectare (1500 to 5000 trees per hectare), having a spindle-like crown form and being intensive plantations. Their attachments are the construction of support and the irrigation system depending on weather and climate conditions. This is strengthened by the fact that primarily such plantations were established in Hungary during the past decade.

In this way, both in Hungary and Germany plantations having the above mentioned parameters got into the data collection. Fixing the above mentioned parameters is important from the farm business aspect, as we cannot speak about the economics, the costs and profitability of apple production in general. The costs, yields and quality in different types of plantations and in enterprises producing on different standard may be totally diverse.

\section{Data requirement of the research}

Firstly, the data requirement being necessary for realizing the objectives of the research determines the method formation. I was attentive to constructing the fruit production activity for determining the necessary data (Figure 1.), regarding that the unit of the analysis is not the venture but a unit technology of 1 hectare, thus I determined the revenues and costs relating to the apple production of a venture to 1 hectare plantation surface.

\section{Production phase}

1. Production

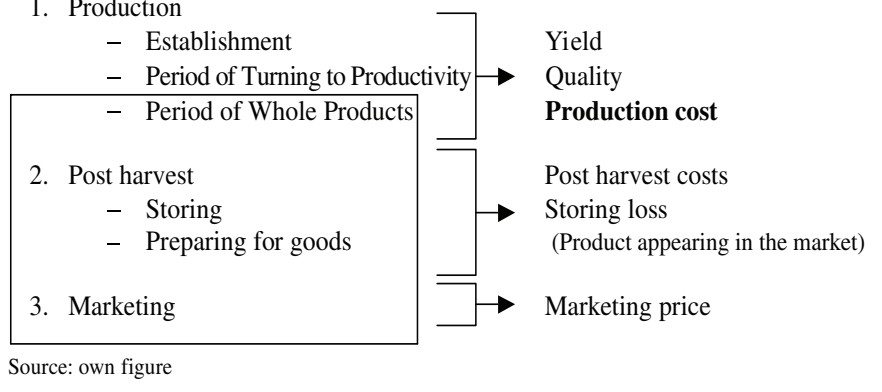

Figure 1. The Three Phases of Fruit Production

\section{Realizing factor (necessary data)}

Yield

Storing loss

(Product appearing in the market)

Marketing price 
On the basis of Figure 1., in order to evaluate the farm business conditions of fruit production, the collection of the following data is necessary:

- natural inputs and input prices for calculating the realized yields and product quality as well as the production costs in the production phase,

- costs of storing and preparing to goods in the post harvest phase, storing loss, and the characteristics of the products (goods) appearing in the market at the end of this process,

- marketing price realized in the sale phase.

By the data above mentioned a complex farm business analysis may be carried out involving every phase of fruit production.

\section{The method of data collection}

Considering the fact that the major ratio of the ventures do not have reliable and precise data on the costs of production due to the lack of appropriate registration, the analysis of the cost side could not be based on collecting cost data, though its determination is the most complex task, and it forms the significant part of the information need of the research (Figure 1.). Collecting natural inputs and constructing the whole production technology seemed to be the proper method, then which cloud be developed into production costs by input prices collected from other sources (not from producing enterprises). Data collection was carried out by the help of data collecting sheets for production created especially for this purpose. Collecting data relating to yields, quality, post harvest costs and storing losses as well as marketing prices is not so complex at all.

Collecting data relating to yields, quality and natural inputs of the production took place exclusively at the producing enterprises, while information on input prices, post harvest costs, storing losses and marketing price may be collected from other sources, and could be improved (e.g. commercial firms turning over plant-protecting agents and fertilizers, firms providing rental services, producer organizations, research institutes, other commercial enterprises). I created the database by mainly primer data collection and to a smaller extent as a supplementary purpose secondary data collection.

I completed my supplementary data collecting work concerning producing enterprises in the Lake Boden Region in Germany, and in the Northern Great Plain Region in Hungary. I reflected the production technology of 7--7 ventures in both countries carried out in plantations having detailed parameters. Data collection occurred from June to August in 2005 in Germany, while in Hungary it happened from November 2005 to April 2006 and involved the collection of production technologies for the years 2004 and 2005. The intensive apple plantation surfaces in the examined enterprises were 158 hectares in Germany and 313 hectares in Hungary.

There was a pervious survey going before this data collection in Hungary in the year 2004 aiming at collecting data for the production technology for the year 2003, which involved 30 plantations of 19 enterprises. There were several types of cultivation systems in these plantations. Though the resulted data do not attach strongly to my investigation, their aim, however, was outstandingly important, for the followings:

- working out, testing and developing the method for data collection,

- investigating horticultural, professional and economic correlations necessary for constructing the farm business model in a broader way,

- revealing the farm business characteristics as well as cost and profit relations of different plantation types.

It is clear that the research work was overtaken by a preparing, testing and developing work based on a greater sample and a broader basic.

\section{Evaluating the data, constructing and operating the model}

The basis of my analyzing and evaluating work of my dissertation is the model constructed by the help of own data collection carried out at producing enterprises and relating to just natural inputs and results of the production.

The model reflects the farm business conditions of the production in a production technology of 1 hectare. This basically means that I neglected the internal enterprise environment (production structure, management, etc.) because of its extremely heterogeneous type and in this way due to its difficult handling and I determined it to 1 hectare. Thus it is not the enterprise which is important but its apple production raising from the venture and clearing it from the internal environment.

The significance of the operation of the model involving seven modules is that the technology constructed by the natural inputs in the 3 . and 4. modules determines the cost and profit conditions as well as the profitability of the plantation investment according to the installed input and output parameters (1. and 2. modules). (Figure 2.)

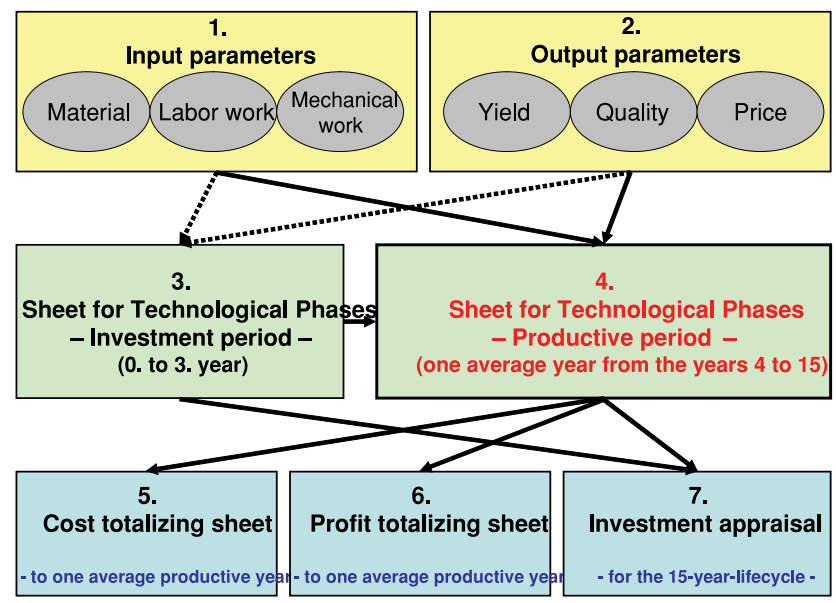

Source: own figure

Figure 2. Structure of the Farm Business Model 
The model is able to evaluate the cost and profit conditions of plantation enterprises in a complex way in case of any technology, and to consider the effects of any changes in input prices (material, machine), wages, yields, quality and marketing prices as well as the effects of subsidies for machine investments, post harvest investments, plantation investments to the cost of farming and to profitability in the short and long run.

I built up mean models both for Hungary and Germany on the basis of the gained experience after evaluating the data of the certain enterprises one by one. These models form the basis for the analyzing and comparing work and reflect the averages of the 7-7 enterprises producing on good standard. The mean models were constructed for a normal year exempt from greater positive or negative weather extremes and plant protecting extremities but naturally they are able to simulate these different states of the reality.

\section{Results and discussion}

I summarize the major findings of my research in harmony with the specific objectives as follows:

\section{What characterizes the natural inputs, costs and as well as their structure?}

Examining the investment costs, I conclude that there are significant differences between the Hungarian and German apple production. The investment cost in Germany is much higher, the difference is 6100 thousand HUF per hectare, that is it is 2,5 times higher. This difference consists of plantation cost of 4800 thousand HUF, and treatment cost of 1300 HUF. Regarding plantation costs, the difference of 4800 thousand HUF between the two countries substitute $35 \%$ planting material, while $60 \%$ equals with the costs of the ice safety system and irrigation system as supplementary establish- ments. Thus, all in all this huge difference may be accounted for the necessity of ice safety system (Table 1.).

Direct cost in Hungary is 1700 thousand HUF per hectare, while in Germany it is 2700 thousand HUF per hectare during the years of operation (productive period). In the Hungarian apple production, near two third of the direct production costs incur during production, a little more than one third of this costs incur during the post harvest period (Table 2.). The costs of plant protection (26\%), harvest (15\%) and fertilizing $(13 \%)$ are significant among the costs during the production period. The depreciation cost of the plantation takes up of $20 \%$, which is the second most significant cost. The most significant costs (Table 2.) are material costs $(33 \%)$ and personal costs $(23 \%)$.

In Germany, three quarter of the direct cost incur during the production period, more than one quarter in the post harvest period. Harvesting cost is outstanding from the costs of production, which consists of $28 \%$ from the total costs of production. This is followed by the depreciation cost $(26 \%)$ and plant protection cost $(20 \%)$. The personal costs are significant ones because of the high wages, which takes up of $39 \%$ of the production phase. It is followed by the depreciation cost due to the extremely high investment costs, which is one quarter of the costs of production. (Table 2.)

It can be concluded that there is a significant difference between the two countries in the direct production costs per hectare in the productive period. The difference is 1000 to 1100 thousand HUF. $90 \%$ of the cost difference occurs in the production phase, while only $10 \%$ incur during the post harvest period. The cost difference of production phase can be explained in 85 to $90 \%$ by the followings: winter pruning, weed control, yield regulation, harvesting and depreciation cost. Moreover, only two costs, harvesting and depreciation costs are responsible in $75 \%$ for the difference. It should be highlighted that these phases except weed control are just the most labor-intensive phases, and the costs difference is thanked not to the technological differences in money but the 400-500\% higher wages in Germany. In case of use of manure and fertilizers, soil cultivation, plant protection and other direct costs, differences to a larger extent cannot be experienced.

There is not any significant difference between material and mechanical costs; the differences are accounted for "tiny tots" (Table 2.) This two cost types are responsible in only $10 \%$ for the difference of 949 thousand HUF in the costs of production phase. The other direct costs are the same, in this way the reasons of the higher German costs are the personal costs and depreciation cost. Personal cost is higher by 540 thousand HUF (by 227\%), the depreciation cost is higher by 316 
Table 2. Cost Structure of Cost Types in the Productive Period*

\begin{tabular}{|c|c|c|c|c|}
\hline \multirow[b]{2}{*}{ Phase } & \multicolumn{2}{|c|}{ Hungary } & \multicolumn{2}{|c|}{ Germany } \\
\hline & $\begin{array}{c}\text { Cost* } \\
\text { (HUF/ha) }\end{array}$ & $\begin{array}{c}\text { Ratio } \\
(\%)\end{array}$ & $\begin{array}{c}\text { Cost* } \\
\text { (HUF/ha) }\end{array}$ & $\begin{array}{c}\text { Ratio } \\
(\%)\end{array}$ \\
\hline Total costs of production & 1042888 & 58.6 & 1991804 & 68.5 \\
\hline Material cost & 349381 & 19.6 & 409233 & 14.1 \\
\hline Personal cost & 237279 & 13.3 & 776550 & 26.6 \\
\hline Mechanical cost & 161404 & 9.1 & 199782 & 6.9 \\
\hline Depreciation of plantation & 205524 & 11.6 & 521999 & 18.0 \\
\hline Other direct cost & 89300 & 5.0 & 84240 & 2.9 \\
\hline Total post harvest cost & 636980 & 35.8 & 740316 & 25.5 \\
\hline Material cost & 79762 & 4.5 & 121311 & 4.2 \\
\hline Personal cost & 60038 & 3.4 & 0 & 0.0 \\
\hline Mechanical and building cost & 394405 & 22.2 & 551805 & 19.0 \\
\hline Bundle depreciation & 63000 & 3.5 & 67200 & 2.3 \\
\hline Other direct cost & 39775 & 2.2 & 0 & 0.0 \\
\hline DIRECT PRODUCTION COST & 1679868 & 94.4 & 2732120 & 94.0 \\
\hline Overhead cost & 100000 & 5.6 & 174000 & 6.0 \\
\hline TOTAL PRODUCTION COST & 1779868 & 100.0 & 2906120 & 100.0 \\
\hline
\end{tabular}

Source: own calculation (*prices of the years 2005-2006.)

thousand HUF (by 153\%) in Germany, and thus the extra costs appear here. There is a significant difference in the post harvest phase only in building costs, of which $97 \%$ is depreciation.

Summarizing the above mentioned, I can conclude that there are two reasons ( 70 to $80 \%$ ) for the difference of 1000 to 1100 thousand HUF between the direct costs per hectare of the two countries: the first is the higher wages in Germany, and the second is the higher establishing costs, which is primarily thanked to the necessity of establishing the ice safety system.

Table 3. The Production Value and its Parameters in the Productive Period*

\begin{tabular}{|c|c|c|c|}
\hline Denomination & Unit & Hungary & Germany \\
\hline TOTAL YIELD & t/ha & 37,00 & 41,00 \\
\hline $\begin{aligned} \text { from which: } & \text { - apple for food, I. class } \\
& \text { - apple for food, II. class. } \\
& \text { - apple for industry purpose }\end{aligned}$ & $\begin{array}{l}\text { t/ha } \\
\text { t/ha } \\
\text { t/ha }\end{array}$ & $\begin{array}{r}28,12 \\
3,70 \\
5,18 \\
\end{array}$ & $\begin{array}{r}34,85 \\
2,46 \\
3,69\end{array}$ \\
\hline Storing loss & $\mathrm{t} / \mathrm{ha}$ & 1,78 & 1,49 \\
\hline MARKETED YIELD & t/ha & 35,22 & 39,51 \\
\hline $\begin{aligned} \text { from which: } & \text { - apple for food, I. class } \\
& \text { - apple for food, II. class. } \\
& \text { - apple for industry purpose }\end{aligned}$ & $\begin{array}{l}\text { t/ha } \\
\text { t/ha } \\
\text { t/ha }\end{array}$ & $\begin{array}{r}26,55 \\
3,49 \\
5,18 \\
\end{array}$ & $\begin{array}{r}33,46 \\
2,36 \\
3,69\end{array}$ \\
\hline $\begin{array}{l}\text { Marketing price: } \\
\qquad \begin{aligned} \text { - apple for food, I. class } \\
\text { - apple for food, II. class. } \\
\text { - apple for industry purpose }\end{aligned}\end{array}$ & $\begin{array}{l}\mathrm{HUF} / \mathrm{kg} \\
\mathrm{HUF} / \mathrm{kg} \\
\mathrm{HUF} / \mathrm{kg}\end{array}$ & $\begin{array}{l}76,10 \\
53,30 \\
20,00 \\
\end{array}$ & $\begin{array}{r}102,50 \\
61,50 \\
25,00\end{array}$ \\
\hline REVENUE & HUF/ha & 2309862,05 & 3666728,40 \\
\hline $\begin{aligned} \text { from which: } & \text { - apple for food, I. class } \\
& \text { - apple for food, II. class. } \\
& \text { - apple for industry purpose }\end{aligned}$ & $\begin{array}{l}\text { HUF/ha } \\
\text { HUF/ha } \\
\text { HUF/ha }\end{array}$ & $\begin{array}{r}2020095,81 \\
186166,24 \\
103600,00\end{array}$ & $\begin{array}{r}3429240,00 \\
145238,40 \\
92250,00\end{array}$ \\
\hline SAPS & HUF/ha & 20000,00 & 0,00 \\
\hline Agrar-environmental subsidy & HUF/ha & 100000,00 & 82000,00 \\
\hline PRODUCTION VALUE & HUF/ha & 2429862,05 & 3748728,40 \\
\hline
\end{tabular}

Source: own calculation (*prices of the years 2005-2006.)

\section{What output levels and parameters (yield, quality, marketing price, production value) characterize the production?}

The Hungarian firms realize an average yield of 37 tons per hectare, $86 \%$ food quality ratio ( $76 \%$ is I. class, $10 \%$ is II. class), and the average price is 76,1 HUF per kilogram for the apple of I. class. Regarding these factors, revenue of 2300 thousand HUF may be reached in the Hungarian apple production. Supplementing this by subsidies, a production value of 2429 thousand HUF may be realized, which is an average value for ventures producing good quality products (Table 3.).

In Germany the average yield is 41 tons per hectare, of which an extremely high ratio, $91 \%$ is food quality, and within this $85 \%$ is I. class, and $6 \%$ is II. class. The average price for the producer is 102,5 HUF per kilogram for the apple of I. class. In the German apple production the revenue is 3666 thousand HUF, which is considered to be an average in a normal case. The revenue supplemented by subsidies results in the production value of 3748 thousand HUF (Table 3.)

To sum up, I conclude that German firms are able to produce higher yields by 4 tons per hectare, but the yield difference relating to the I. class products is near 7 tons per hectare. Considering these yield and price parameters, German firms can reach higher revenue by 1300 to 1400 thousand HUF or by 55 to $60 \%$ per hectare.

What are the tendencies of the efficiency and economies of production from short-term and long-term aspects?

In Hungarian apple production, under a normal condition, a contribution of 750 thousand HUF may be expected from firms producing good quality products. After regarding the overhead cost a net profit of 650 thousand HUF may be reached. Under average and normal conditions, German firms can reach 1016 thousand HUF contribution per hectare, which is a net profit of 843 thousand HUF per hectare when considering overhead costs.

Investigating the profitability of apple in a short run, it can be summarized that German firms realizing 55 to $60 \%$ higher production value and 60 to $65 \%$ higher 
Table 4. Results of Farming in the Productive Period*

\begin{tabular}{|l|c|r|r|}
\hline \multicolumn{1}{|c|}{ Denomination } & \multicolumn{1}{c|}{ Unit } & \multicolumn{1}{c|}{ Hungary } & Germany \\
\hline PRODUCTION VALUE & HUF/ha & $\mathbf{2 4 2 9} \mathbf{8 6 2}$ & $\mathbf{3 7 4 8 ~ 7 2 8}$ \\
\hline Direct production cost & HUF/ha & 1679868 & 2732120 \\
\hline CONTRIBUTION & HUF/ha & $\mathbf{7 4 9 ~ 9 9 4}$ & $\mathbf{1 0 1 6 6 0 8}$ \\
\hline Overhead cost & HUF/ha & 100000 & 174000 \\
\hline Total production cost & HUF/ha & 1779868 & 2906120 \\
\hline NET PROFIT & HUF/ha & $\mathbf{6 4 9 9 9 4}$ & $\mathbf{8 4 2 ~ 6 0 8}$ \\
\hline Total depreciation cost & HUF/ha & 705490 & 1197923 \\
\hline Operation cost (expense) & HUF/ha & 1074377 & 1708197 \\
\hline CASH FLOW & HUF/ha & $\mathbf{1 3 5 5} \mathbf{4 8 4}$ & $\mathbf{2 0 4 0 ~ 5 3 1}$ \\
\hline
\end{tabular}

Source: own calculation (*prices of the years 2005-2006.)

Table 5. Investment Efficiency Indicators of Apple Production in the Two Countries

\begin{tabular}{|l|c|c|c|}
\hline \multicolumn{1}{|c|}{ Denomination } & Unit & Hungary & Germany \\
\hline NPV (Net Present Value)* & $\begin{array}{c}\text { Thousand } \\
\text { HUF/ha }\end{array}$ & 2492 & 4239 \\
\hline DPP (Discounted Payback Period) & year & 9 & 10 \\
\hline PI (Profitability Index) & - & 1,80 & 1,54 \\
\hline IRR (Internal Rate of Return) & $\%$ & 15,3 & 9,9 \\
\hline Source: own calculation & & & \\
\hline
\end{tabular}

*Hungary: $r=7 \%$; Germany: $r=4 \%$

production cost are able to produce 35 to $40 \%$ higher contribution, which means 250 to 300 thousand HUF per hectare surplus contribution (Table 4.).

Investigating the profit in a long run, that is reflecting the economies of the plantation investment for the whole lifecycle, it can be stated that the production in Hungary may be carried out in a profitable way concerning the above mentioned yields, quality and price and considering 7\% calculative interest rate. At the end of the lifetime of the investment, that is in the $15^{\text {th }}$ year, NPV of 2492 thousand HUF is reached. The returning happens in the $9^{\text {th }}$ year, the IRR is $15,3 \%$ (Table 5.).

The German apple production can be carried out also in an effective way realizing the above mentioned yields, quality and prices, as well as considering $4 \%$ calculative interest rate. At the end of the lifetime, NPV of 4239 thousand HUF is reached, the payback period is 10 years (Figure 3.), the IRR is $9,9 \%$.

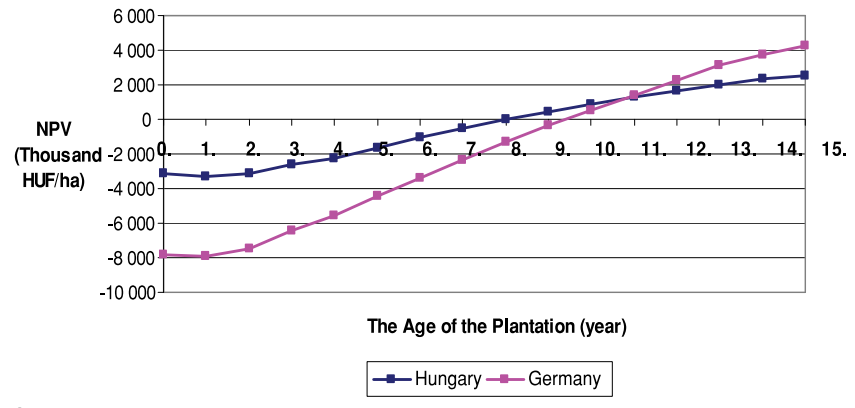

Source: own calculation

Hungary: $r=7 \%$; Germany: $r=4 \%$

Figure 3. The NPV* in the Hungarian and German Apple Production
When comparing the economic aspects of the investment, it is clear that the efficiency (NPV) in absolute value is more favourable in Germany than in Hungary, while the IRR reflecting the average, annual profit to asset ratio is more approving in Hungary. There is not a great difference between the payback periods of the investment; in Hungary the returning happens in the $9^{\text {th }}$ year, while in Germany in the $10^{\text {th }}$ year (Table 5.).

\section{What characterizes the profitability if the different states of external environment, such as investment subsidies, yields, quality and marketing price are changing?}

Examining the economic aspects of Hungarian and German apple production determined to the whole lifecycle, without investment subsidies and considering the same calculative interest rate for both countries, I can conclude that (Table 6. and 7.) the profit (NPV) in absolute amount is more favourable in Hungary in case of a realistic case, while it is more approving in Germany in an optimistic view, while under a pessimistic condition the economic aspects are unfavourable in both countries, the returning does not occur even during the whole lifecycle of the plantation.

Table 6. Investment Efficiency in Hungarian Apple Production without Investment Subsidies

\begin{tabular}{|l|c|c|c|c|}
\hline Denomination & Unit & $\begin{array}{c}\text { Optimistic } \\
\text { scenario }\end{array}$ & $\begin{array}{c}\text { Realistic } \\
\text { scenario }\end{array}$ & $\begin{array}{c}\text { Pessimistic } \\
\text { scenario }\end{array}$ \\
\hline NPV $(\mathrm{r}=7 \%)$ & $\begin{array}{c}\text { Thousand } \\
\text { HUF/ha }\end{array}$ & 5960 & 2492 & -443 \\
\hline DPP & year & 6 & 9 & $>15$ \\
\hline PI & - & 2,92 & 1,80 & 0,86 \\
\hline IRR & $\%$ & 23,6 & 15,3 & 5,1 \\
\hline
\end{tabular}

Source: own calculation

Table 7. Investment Efficiency in German Apple Production without Investment Subsidies

\begin{tabular}{|l|c|c|c|c|}
\hline Denomination & Unit & $\begin{array}{c}\text { Optimistic } \\
\text { scenario }\end{array}$ & $\begin{array}{c}\text { Realistic } \\
\text { scenario }\end{array}$ & $\begin{array}{c}\text { Pessimistic } \\
\text { scenario }\end{array}$ \\
\hline NPV $(\mathrm{r}=7 \%)$ & $\begin{array}{c}\text { Thousand } \\
\text { HUF/ha }\end{array}$ & 7620 & 1764 & -3224 \\
\hline DPP & year & 8 & 12 & $>15$ \\
\hline PI & - & 1,97 & 1,22 & 0,59 \\
\hline IRR & $\%$ & 17,5 & 9,9 & 0,3 \\
\hline
\end{tabular}

Source: own calculation

Moreover, the payback period (DPP) and indicators reflecting profit to asset ratio (IRR, PI) are better in every case under Hungarian conditions, which is thanked to the much lower establishing costs.

Considering investment subsidies, the result in absolute amount is more encouraging in Germany in case of optimistic scenario; in case of realistic and pessimistic scenarios it is more favourable in Hungary, while profit to asset ratio is more approving in Hungary in every case (Table 8. and 9.) 
Table 8. Investment Efficiency in Hungarian Apple Production Regarding Investment Subsidies

\begin{tabular}{|l|c|c|c|c|}
\hline Denomination & Unit & $\begin{array}{c}\text { Optimistic } \\
\text { scenario }\end{array}$ & $\begin{array}{c}\text { Realistic } \\
\text { scenario }\end{array}$ & $\begin{array}{c}\text { Pessimistic } \\
\text { scenario }\end{array}$ \\
\hline NPV $(\mathrm{r}=7 \%)$ & $\begin{array}{c}\text { Thousand } \\
\text { HUF/ha }\end{array}$ & 8661 & 5187 & 2246 \\
\hline DPP & year & 4 & 5 & $>7$ \\
\hline PI & - & 6,10 & 4,05 & 2,32 \\
\hline IRR & $\%$ & 40,6 & 31,0 & 20,2 \\
\hline
\end{tabular}

Source: own calculation

Table 9. Investment Efficiency in German Apple Production Regarding Investment Subsidies

\begin{tabular}{|l|c|c|c|c|}
\hline Denomination & Unit & $\begin{array}{c}\text { Optimistic } \\
\text { scenario }\end{array}$ & $\begin{array}{c}\text { Realistic } \\
\text { scenario }\end{array}$ & $\begin{array}{c}\text { Pessimistic } \\
\text { scenario }\end{array}$ \\
\hline NPV $(\mathrm{r}=7 \%)$ & $\begin{array}{c}\text { Thousand } \\
\text { HUF/ha }\end{array}$ & 10438 & 4582 & -406 \\
\hline DPP & year & 6 & 8 & $>15$ \\
\hline PI & - & 2,96 & 1,86 & 0,92 \\
\hline IRR & $\%$ & 25,2 & 16,4 & 5,9 \\
\hline
\end{tabular}

Source: own calculation

Investment subsidies improve the reachable NPV by 2700 to 2800 thousand HUF in both countries, and in Hungary they make the production profitable even under pessimistic conditions, while in Germany it is not true even in this case.
All in all, the conclusion can be made that the investment subsidies make the farming of Hungarian apple producing firms more calculable from the economic aspect, without them the profitability may be extremely bad in case of a more unfavourable situation.

\section{Conclusions}

The profitability of the Hungarian apple production considering firms producing on high standard is not lagged behind significantly from that of German firms, moreover in certain cases it reflects a more positive situation. It is unfavourable, however, that this statement is true only for 8 to $10 \%$ of our whole apple plantation surface.

The results of the investigations highlighted the fact that in comparison with Germany our farm business advantages manifest in three factors: in 70 to $80 \%$ lower wages, in 15 to $30 \%$ higher investment and subsidy intensity and in the fact that at present we cannot neglect the ice safety system which is rather expensive. By the increasing wages, the narrowing subsidy opportunities and incidentally the appearing harmful weather phenomenon, these advantages may be continuously ceased. Our definite disadvantage appears in the level of marketing price, considering the fact that producers in Hungary realize 30 to $35 \%$ lower marketing price, which is in connection with the probably much lower level of organization among farmers, in the market and in the logistical background. 